\author{
KAMILA ZióŁKOWSKA-WEISS \\ Uniwersytet Pedagogiczny w Krakowie, Polska • Pedagogical University of Cracow, Poland
}

\title{
Zachowania konsumenckie Polaków korzystajqcych z oferty polsko-egipskich biur podróży w Szarm el-Szejk
}

\author{
Consumers' Behaviour of Poles \\ Using Polish-Egyptian Travel Agencies in Sharm el Sheikh
}

\begin{abstract}
Streszczenie: Egipt jest coraz popularniejszy wśród polskich turystów. Wyjazdom do tego państwa sprzyja niezwykle korzystna cena wycieczek w porównaniu z ofertami innych nadmorskich krajów. Jedną z przyczyn tego stanu jest fakt, że Egipt stanowi jedną z tzw. destynacji dolarowych. W sytuacji, gdy kurs dolara w stosunku do euro jest niższy, a złotówka ma silną pozycję wobec obu tych walut, wycieczki do Egiptu mają bardzo atrakcyjne ceny. Główny cel przyjazdu do Egiptu to: turystyka wypoczynkowa (piękne plaże), kursy nurkowania, snorkeling, windsurfing, żeglarstwo, jachting, wędkarstwo, golf oraz turystyka poznawcza. Intensywność zainteresowania oraz możliwości finansowe potencjalnych turystów spowodowały powstanie lokalnych biur podroży, które zajęły się zaspokajaniem nowych potrzeb - przygotowaniem ofert turystyki i wypoczynku. Co roku do Egiptu przybywa duża liczba polskich turystów, którzy pragną poznać i zwiedzić ten kraj. W związku z tym w egipskich kurortach powstają polsko-egipskie biura podróży oferujące turystom lokalne, fakultatywne wycieczki. W artykule omówiono działalność największych polsko-egipskich biur podróży w Szarm el-Szejk (ang. Sharm el-Sheikh), takich jak: E-Sharm.Pl, Słoneczny Sharm, PolSharm, czy Esti Tours. Autorka przedstawia wyniki badań, które przeprowadziła w sierpniu 2015 roku w Szarm el-Szejk wśród polskich turystów, którzy korzystali z usług lokalnych biur podróży. Zaprezentowano dane o tym, jaką formę turystyki i wypoczynku preferują ankietowani w Egipcie, co skłoniło ich do skorzystania z usług danego biura podróży, jak dowiedzieli się o jego istnieniu, w ilu fakultatywnych wycieczkach uczestniczyli, czym kierowali się przy wyborze lokalnego biura oraz ile pieniędzy wydali w polsko-egipskich biurach podróży działających w Szarm el-Szejk. Dokonano również analizy najczęściej wybieranych przez polskich turystów wycieczek fakultatywnych oraz oceny ich organizacji.
\end{abstract} Abstract: Egypt is more and more popular with Polish tourist. The extremely affordable price of the events
as compared to offers of other coastal states favours the trips. One of the reasons is the fact that Egypt con-
stitutes one of the so-called "dollar destinations". This means that tour operators organizing events in this
country settle in the US dollars. In the situation when the US dollar exchange rate is lower in relation to
the euro and the Polish zloty is strong in relation to both these currencies, trips to Egypt have very attrac-
tive prices. The main purpose of tourists coming to Egypt is recreational tourism (beautiful beaches), diving
courses, snorkelling, windsurfing, sailing, yachting, fishing, golf and cultural tourism. Intensity of the interest
and financial capabilities of the potential clients have resulted in the formation of local travel agencies that
deal with satisfying new needs. This happened through creating offers regarding tourism and recreation. The
annual significant number of the Polish tourists coming to Egypt who want to get to know and visit it has con-
tributed to the fact that Polish-Egyptian travel agencies that offer local optional trips to tourists are opened in
the Egyptian resorts. The paper discusses the activity of the largest Polish-Egyptian travel agencies in Sharm 
el Sheikh, such as E Sharm.Pl, Sunny Sharm, PolSharm, Sunny Shore or Egypt Tours. The author presents the results of the research that was conducted in August 2015 in Sharm el Sheikh among the Polish tourists who had used the services provided by the local travel agencies. The data determining which form of tourism and recreation the respondents in Egypt prefer, what made them use the services of the specific travel agency, how they got to know about its existence, how many optional trips they participated in, what they were driven by while choosing the local travel agency and how much money they spent in the Polish-Egyptian travel agencies providing services in Sharm el Sheikh. The analysis of the optional trips that are most frequently chosen by the Polish students and assessment of their organization is also provided.

Słowa kluczowe: biura podróży; Egipt; Szarm el-Szejk; turystyka międzynarodowa; wycieczka

Keywords: Egypt; international tourism; Sharm el Sheikh; travel agencies; trip

Otrzymano: 9 stycznia 2016

Received: 9 January 2016

Zaakceptowano: 17 lipca 2016

Accepted: 17 July 2016

Sugerowana cytacja / Suggested citation:

Ziółkowska-Weiss, K. (2016). Zachowania konsumenckie Polaków korzystających z oferty polsko-egipskich biur podróży w Szarm el-Szejk. Prace Komisji Geografii Przemysłu Polskiego Towarzystwa Geograficznego, 30(4), 102-118.

\section{WSTĘP}

Turystyka ma ogromne znaczenie w kształtowaniu światowej gospodarki. W wielu krajach stała się ważnym źródłem dochodów i miejscem pracy oraz czynnikiem aktywizującym rozwój regionalny i lokalny. Dynamiczny wzrost wielkości ruchu turystycznego na świecie możliwy był dzięki licznym zmianom ekonomicznym, społecznym, technologicznym i politycznym. Jego wpływ na warunki przyrodnicze, ekonomiczne i społeczne ma coraz większe znaczenie. Turystyka jest obecnie jednym z najważniejszych przejawów aktywności życiowej człowieka. Jest też jedną z najbardziej dochodowych działalności świata, o czym świadczy analiza międzynarodowego ruchu turystycznego. Zgodnie z nią liczba turystów zagranicznych zwiększyła się z około 25 mln w 1950 roku do ponad 700 mln w 2003 roku (Mika, Faracik, 2008). Obecnie najbardziej ostrożne statystyki wskazują, że rocznie rejestruje się ponad miliard podróży ludności naszej planety odbywanych w celach turystycznych (UNWTO, 2013). Według danych Światowej Organizacji Turystyki (United Nations World Tourism Organization, UNWTO) liczba podróży stale rośnie.

Według Światowej Rady Podróży i Turystyki (World Travel \& Tourism Council, WTTC) gospodarka turystyczna ma ponad 9\% udziału w globalnym produkcie brutto na świecie i daje ponad 7,5\% zatrudnienia. Te dwa wskaźniki pokazują jej realną ekonomiczną i społeczną pozycję we współczesnym świecie. Powodują tym samym sprzężenie zwrotne pomiędzy rozwojem turystyki a pozostałymi działami gospodarki w różnych układach regionalnych (Dziedzic, Łopaciński, Saja, Szegidewicz, 2009).

Już po II wojnie światowej turystyka zaczęła pełnić ważną funkcję w gospodarczym życiu Egiptu. W kolejnych latach rozwijający się przemysł turystyczny nie tylko przyczynił się do rozbudowy infrastruktury kraju, ale - co ważniejsze - wpłynął 
na wzrost zatrudnienia mieszkańców bezpośrednio lub pośrednio przy obsłudze ruchu turystycznego (Al Hamarneh, 2006). W wyniku zawierania przez Egipcjan coraz większej liczby małżeństw z obywatelkami Europy Zachodniej na rynek egipski zaczęły napływać prywatne oszczędności (głównie z Niemiec). Wzrost zainteresowania Afryką Północną przyczynił się do napływu kapitału z krajów Zatoki Perskiej (Marciniak, Dłużewska, 2015). Pozwoliło to na budowę sieci luksusowych hoteli i wiosek turystycznych, położonych głównie nad Morzem Czerwonym. Od połowy lat osiemdziesiątych XX wieku rozpoczęła się budowa powszechnie już znanych kurortów w Szarm el-Szejk oraz w Hurghadzie (Gray, 1998).

W wyniku postępującej globalizacji, która dawała nadzieję na rozwój kraju i wprowadzenie w nim potrzebnych zmian, zaczęto myśleć o turystyce w kategorii wielkiego biznesu. Inwestowanie $\mathrm{w}$ ten sektor gospodarki stało się sprawą bardzo istotną dla całego kraju (Tohamy, Swinscoe, 2000).Wraz z rozwojem turystyki w Egipcie zaczęły powstawać lokalne biura podróży, które organizowały wycieczki fakultatywne dla przyjeżdżających turystów.

Powstawanie biur podróży należy wiązać z żywiołowym rozwojem ruchu turystycznego w pierwszej połowie XIX wieku. Pod wpływem coraz większego w tym czasie uprzemysłowienia, postępu technicznego i organizacyjnego, sprzyjającego wzrostowi wydajności pracy i stopniowemu skracaniu czasu pracy, ustawowego wprowadzenia płatnych urlopów i wzrostu dochodów ludności doszło do zmian w strukturze konsumpcji, których wyrazem było ujawnienie się nowych potrzeb w zakresie wypoczynku i turystyki. Intensywność zainteresowania oraz możliwości finansowe potencjalnych turystów spowodowały powstanie lokalnych biur podroży, które zajęły się zaspokajaniem nowych potrzeb, polegającym na tworzeniu ofert dotyczących turystyki i wypoczynku (Cook, 2008).

Celem artykułu jest omówienie działalności największych polsko-egipskich biur podróży w Szarm el-Szejk, takich jak: E-Sharm.Pl, Słoneczny Sharm, PolSharm, czy Esti Tours, oraz przedstawienie wyników badań, mówiących o tym, jaką formę turystyki i wypoczynku preferują ankietowani w Egipcie, co skłoniło ich do skorzystania z usług danego biura podróży, jak dowiedzieli się o jego istnieniu, w ilu fakultatywnych wycieczkach uczestniczyli, czym kierowali się przy wyborze lokalnego biura oraz ile pieniędzy wydali w polsko-egipskich biurach podróży działających w Szarm el-Szejk.

\section{PRZEBIEG ORAZ ZAKRES CZASOWY I PRZESTRZENNY BADAŃ EMPIRYCZNYCH}

Badanie podjęto, aby przeanalizować działalność polsko-egipskich biur podróży w Szarm el-Szejk oraz określić najpopularniejsze wycieczki fakultatywne wybierane przez wypoczywających tam Polaków. Zasadniczym obszarem badania było miasto na półwyspie Synaj, Szarm el-Szejk. Zostało ono przeprowadzone w sierpniu 2015 roku wśród polskich turystów, którzy korzystali z usług lokalnych biur podróży. W sumie w badaniu wzięło udział 237 osób (w wieku od 18 do 65 lat). Po analizie kwestionariuszy ankietowych odrzucono $12 \mathrm{z}$ nich z powodu nieczytelności oraz nierzetelności w odpowiedziach. Ostatecznie uzyskano 225 kwestionariuszy ankietowych, które poddano analizie. 
Badanie przeprowadzono wśród Polaków w kilku hotelach w Szarm el-Szejk oraz na lotnisku wśród polskich turystów wracających po urlopie do Polski w drugiej połowie sierpnia 2015 roku. Kwestionariusz ankietowy skierowany był tylko do osób, które korzystały z wycieczki fakultatywnej oferowanej przez dowolne polsko-egipskie biuro podróży działające w Szarm el-Szejk. Informacja ta została podana respondentom na początku badania.

Narzędziem badawczym był kwestionariusz ankietowy składający się z 10 pytań oraz krótkiej metryczki. Drugim narzędziem badawczym wykorzystanym podczas badań terenowych w Szarm el-Szejk, należącym do metod jakościowych, były indywidualne wywiady (tzw. IDI) z właścicielami i pracownikami wybranych polsko-egipskich biur podróży działających w tym mieście.

Badania jakościowe w naukach społecznych opierają się na założeniu, że do badania niektórych problemów lepiej nadają się pogłębione analizy mniejszej liczby przypadków niż powierzchowne dużej (Silverman, 2008; Flick, 2012). Ponadto uważa się, że wiele spraw lepiej jest badać przez dogłębne zrozumienie rzeczywistości w oczach aktorów społecznych danej zbiorowości niż poprzez wykorzystanie wcześniej przygotowanego modelu teoretycznego (jak zazwyczaj jest w metodach ilościowych) (Jemielniak, 2012). Badania jakościowe w porównaniu z ilościowymi są mało usystematyzowane. $\mathrm{Z}$ racji braku podejścia ilościowego nie stosuje się $\mathrm{W}$ nich wnioskowania statystycznego. Celem nie jest poznanie, ile osób tak myśli, lecz jak odmiennie ludzie myślą na dany temat. Istnieje wiele zalet badań jakościowych. Dostarczają m.in. informacji o badanym zjawisku, o nowej jakości, pogłębiają zdobytą wiedzę oraz pomagają lepiej zrozumieć mechanizmy działania analizowanych zagadnień (Jemielniak, 2012). W trakcie prowadzenia wywiadów i badań ankietowych autorka stosowała również swobodną obserwację, zaliczaną do metod jakościowych. Pozwoliło to dopełnić dane zdobyte w trakcie ankietowania i wywiadów. Jak wynika z definicji obserwacji, jest to metoda wstępna, polegająca na gromadzeniu informacji (Mazurek-Łopacińska, 2005).

\section{WPŁYW SYTUACJI POLITYCZNEJ NA TURYSTYKĘ W EGIPCIE}

W 2005 roku, po ok. pięcioletnim okresie widocznej stagnacji czy wręcz kryzysu w gospodarce Egiptu, spowodowanego m.in. utrzymującą się recesją światową i niestabilną sytuacją w regionie (zamach na World Trade Center, palestyńska intifada, działania zbrojne w Iraku), jak również narastającymi trudnościami wewnętrznymi (brak płynności miejscowej waluty - funta i jej silna dewaluacja, rosnące bezrobocie, wysoka inflacja, pogłębiający się deficyt budżetowy, ograniczony dostęp do dewiz, a przez to ograniczone możliwości płatnicze tutejszych importerów, spadek dochodów w kluczowych działach gospodarki: turystyce, eksploatacji Kanału Sueskiego oraz transferach z zagranicy), odnotowano ożywienie koniunktury i poprawę wskaźników makroekonomicznych kraju prawie we wszystkich dziedzinach gospodarki.

W usługach od lat szczególne znaczenie dla budżetu egipskiego państwa mają wpływy z turystyki, które stanowią 10-15\% PKB. Pomimo lipcowego zamachu terrorystycznego w Szarm el-Szejk rok 2005 okazał się wyjątkowo pomyślny dla sektora turystyki - odnotowano rekordowe wyniki, zarówno w liczbie przyjazdów do Egiptu, jak 
i w osiągniętych dochodach. 23 lipca 2005 roku doszło w mieście do zamachów bombowych, w wyniku których zginęły 64 osoby (wg niepotwierdzonych szacunków mogło to być nawet 88 osób), a ok. 200 zostało rannych. Jak podaje Ministerstwo Turystyki, kraj ten odwiedziło w 2005 roku blisko 8,7 mln turystów (wzrost o ok. 15\% w stosunku do roku 2004), pozostawiwszy w nim 6,5 mld dol. (5,5 mld dol. w 2004 roku).

W 2008 roku Egipt odnotował niewielkie straty w sektorze turystycznym. Miał na to wpływ światowy kryzys gospodarczy, który w pełni uwidocznił się w drugiej połowie tego roku. Dotknął on większości branż i gospodarek narodowych, w tym również turystyki (Zdon-Korzeniowska, Rachwał, 2011). W tym sektorze odczuwalny stał się nacisk światowej recesji gospodarczej, zwłaszcza w takich kwestiach, jak wielkość inwestycji turystycznych, rentowność przedsiębiorstw turystycznych i wielkość ruchu turystycznego (Gotowt-Jeziorska, Łopaciński, 2011). Jak zauważyli S. Kurek i P. Wacławik (2013), kryzys gospodarczy i finansowy z 2008 roku spowodował zmniejszenie popytu na usługi turystyczne. W 2009 roku obroty europejskiej branży turystycznej spadły więc o ok. 5,6\% (UNWTO World Tourism Barometer, 2010). Turyści europejscy decydowali się na krótsze i bliższe wyjazdy oraz ograniczali wydatki w miejscach pobytu. Poza Rosjanami do Egiptu przybywają głównie turyści z Unii Europejskiej. Kryzys gospodarczy w branży turystycznej, o którym piszą Kurek i Wacławik (2013), niewątpliwie niekorzystnie odbił się na wielkości ruchu turystycznego w tym kraju.

Egipt, wraz z obaleniem prezydenta Husniego Mubaraka i po przeprowadzeniu pierwszych wolnych wyborów parlamentarnych i prezydenckich na przełomie 2011 i 2012 roku, formalnie wkroczył na drogę budowy systemu demokratycznego. W rzeczywistości obalenie dotychczasowego prezydenta przyniosło inny rodzaj dyktatury dyktaturę radykalnego Bractwa Muzułmańskiego, które - podobnie jak w innych krajach regionu - zwyciężyło w wyborach. Stosunek Bractwa do turystyki można określić jako osobliwy (Marciniak, Dłużewska, 2015).

Jednym z pierwszych postulatów nowego rządu było dostosowanie norm obowiązujących turystów przebywających w Hurghadzie czy Szarm el-Szejk do prawa szariatu (np. zakaz dystrybucji alkoholu, zakaz odkrywania ciała). Lukę po (ewentualnie, acz niekoniecznie) rezygnujących turystach zachodnich mieli wypełnić turyści z krajów muzułmańskich. Innym pomysłem było zamknięcie dla turystów obiektów niezgodnych z wartościami islamu (np. piramid w Gizie czy zabytków starożytnego Egiptu). Pomysły Bractwa nie zostały wcielone w życie - rząd dosyć szybko zdał sobie sprawę, że ich realizacja oznaczałaby koniec turystyki - zachwiały jednak i tak mocno osłabioną reputacją kraju, ukazując go jako nieodpowiedzialny i niestabilny.

Skutki arabskiej wiosny w Egipcie wyraźnie widoczne są na przykładzie sektora turystycznego. Przychody z turystyki w tym kraju w 2010 roku wynosiły 12,5 mld dol., podczas gdy rok później - zaledwie 8,7 mld dol. i jak do tej pory suma ta nie wróciła do wyniku sprzed rewolucji (Campas, 2015). Wraz z mniejszą liczbą turystów odwiedzających Egipt - a co za tym idzie ze zmniejszeniem się wpływów z turystyki - odnotowano wzrost bezrobocia, które od 2011 roku ciągle rośnie. W pierwszym kwartale 2010 roku wskaźnik bezrobocia wynosił 9,12\%, w 2011 roku 11,9\%, by w pierwszym kwartale 2014 roku osiągnąć wartość 13,4\%. 
Zdaniem D. Abdou i Z. Zaazou (2013: 98) turystyka odczuła negatywne skutki arabskiej wiosny nie tylko w Egipcie, ale również w całym regionie, gdzie spadek liczby turystów był bliski 45\% w pierwszym kwartale 2011 roku. J. Zdanowski (2013: 24) i R. Fiedler (2014: 42) także zauważyli spowolnienie gospodarcze Tunezji i Egiptu, do którego doszło po wybuchu rewolucji. Ponadto zwrócili oni uwagę na dynamiczne wydarzenia polityczne oraz ich odstraszający wpływ zarówno na turystów, jak i na inwestorów zagranicznych, którzy swój kapitał przekierowali do bardziej ustabilizowanych politycznie krajów. Fiedler (2014: 42) mówi też o wpływie niepokojów politycznych w 2012 roku na trwałe obniżenie ruchu turystycznego. W 2010 roku Egipt odwiedziło 14,7 mln osób, w tym 600 tys. Polaków, a w 2014 r. było ich 9,8 mln - w tym 400 tys. Polaków.

Pomimo niestabilnej sytuacji polityczno-gospodarczej Egipt jest popularną destynacją wśród polskich turystów. Wyjazdom sprzyja ich niezwykle korzystna cena w porównaniu z ofertami innych nadmorskich krajów, zwłaszcza takich jak Hiszpania, Włochy czy Grecja. Przyczyn takiego stanu rzeczy jest kilka. Przede wszystkim, Egipt jest jedną z tzw. destynacji dolarowych. Oznacza to, że touroperatorzy organizujący imprezy w tym kraju rozliczają się w dolarach. W sytuacji, gdy kurs dolara w stosunku do euro jest niższy, a złotówka ma bardzo silną pozycję wobec obu tych walut, wycieczki do Egiptu mają bardzo atrakcyjne ceny. Nie bez znaczenia pozostaje też fakt, że państwo to jest destynacją całoroczną - bardzo popularne są wyjazdy w miesiącach zimowych, gdy kurorty w krajach europejskich są nieczynne.

Wśród odwiedzających Egipt największą grupę stanowią turyści z Europy Zachodniej - głównie z Niemiec, Wielkiej Brytanii, Francji, Holandii, Skandynawii i Polski. Kolejna ważna grupa, zostawiająca w tym kraju duże pieniądze, to Rosjanie. Jednak po zamachu terrorystycznym we wrześniu 2015 roku na rosyjski samolot lecący z Szarm el-Szejk do Moskwy rząd rosyjski wstrzymał loty rosyjskich turystów do tego państwa. W ostatnim kwartale 2015 roku Ministerstwo Turystyki w Egipcie odnotowało znaczący spadek przyjazdów turystów, a co za tym idzie również spadek dochodów w sektorze turystycznym.

\section{DZIAŁALNOŚĆ POLSKO-EGIPSKICH BIUR PODRÓŻY W SZARM EL-SZEJK}

Szarm el-Szejk to miasto w południowej części półwyspu Synaj, leżące nad Morzem Czerwonym, w odległości 80 km od góry Synaj. Miasto dzieli się na dwie główne dzielnice: Old Market, czyli pierwotną część miasta, oraz leżącą w odległości ok. 7 km Na'ama Bay - główne centrum turystyczne. W okolicach Szarm el-Szejk działa ponad 500 różnej klasy hoteli. 20 km za miastem znajduje się międzynarodowe lotnisko. Podstawą gospodarki Szarm el-Szejk jest turystyka: uprawianie sportów wodnych, np. nurkowania i snorkelingu. Infrastruktura turystyczna rozwinięta jest na zadowalającym poziomie: hotele i restauracje kilku dużych, międzynarodowych sieci, takich jak Hilton, Marriott czy Sheraton, pola golfowe oraz wiele innych obiektów rekreacyjnych sprawiają, że miasto jest atrakcyjne dla zagranicznych turystów (Sattin, Franquet, 2003).

W Szarm el-Szejk działa kilkanaście polsko-egipskich biur podróży, specjalizujących się w organizacji wycieczek fakultatywnych. Są to lokalne biura, które w dużej 
mierze prowadzone są wspólnie przez Polaków i Egipcjan. W każdym z tych biur pracuje chociaż jedna osoba pochodzenia polskiego oraz egipskiego. Do głównej pracy Polaków należy przede wszystkim bezpośredni kontakt z rodakami w celu zachęcenia ich do kupna danej oferty. Bardzo często praca ta zaczyna się już na polskim lotnisku - podróżnym do Egiptu rozdawane są broszury z informacją o wycieczkach fakultatywnych organizowanych w docelowym miejscu oraz o lokalnym biurze podróży i jego ofercie.

Do zadań Polaków w Szarm el-Szejk należy również kontakt z polskimi turystami w hotelach w Egipcie. Pracownicy lokalnych biur podróży przyjeżdżają na umówione miejsce spotkania (zazwyczaj jest to hotel, w którym turyści wypoczywają) i opowiadają, reklamując poszczególne wycieczki, a tym samym zachęcają do ich zakupu. Do głównych zadań Egipcjan należy przede wszystkim praca związana z organizacją wycieczek, od ustalenia i rezerwacji transportu, przez negocjację cen w obiektach turystycznych, po - co najważniejsze - przewodnictwo i pilotaż wycieczek fakultatywnych. Egipcjanie - dzięki temu, że bardzo dobrze posługują się językiem polskim i znają polską kulturę - wzbudzają zaufanie polskich turystów, a dodatkowo fakt, że są u siebie, sprawia, że osoby uczestniczące w wycieczce czują się bezpiecznie i pewnie.

Do największych i najprężniej działających polsko-egipskich biur podróży w Szarm el-Szejk należą: E-Sharm.Pl, Słoneczny Sharm, PolSharFm i Esti Tours.

E-Sharm.Pl jest największym lokalnym biurem podróży. Poza licznymi wycieczkami fakultatywnymi, które ma w swojej ofercie, proponuje podróżnym również wyjazdy nurkowe, wynajęcie przewodnika po Egipcie oraz organizację wyjazdu do tego kraju dla zorganizowanej grupy i przygotowanie dla niej konkretnej, specjalnej oferty. Poza wycieczkami biuro proponuje również kupno wczasów w Szarm el-Szejk za jego pośrednictwem oraz możliwość wynajęcia lub kupna nieruchomości w tym mieście. Na uwagę zasługuje fakt, że do dyspozycji turystów jest działający przez cały rok polski numer telefonu. Jeszcze przed wylotem na wakacje można skonsultować się z osobą w Polsce, która doradzi nam wycieczkę oraz dokona za nas rezerwacji na konkretny dzień pobytu w Egipcie.

Biuro podróży Słoneczny Sharm działa od sześciu lat i założyło je młode polsko-egipskie małżeństwo. Na wycieczkach biuro zapewnia doświadczonych przewodników - Polaków i polskojęzycznych Egipcjan, którzy swój warsztat językowy szkolili zarówno w egipskich, jak i w polskich szkołach językowych. Wszystkie wycieczki odbywają się na podstawie oficjalnych zezwoleń Egipskiej Straży Turystycznej.

Polsko-egipskie biuro podróży PolSharm ma swoją siedzibę w Szarm el-Szejk i w Nowym Sączu. Zajmuje się organizacją lokalnych wycieczek w Egipcie z polskim przewodnikiem. Współpracuje z biurami podróży i agencjami turystycznymi w Polsce. Przed wylotem turyści w Polsce mogą kontaktować się z przedstawicielami biura e-mailem lub wysyłając SMS-a na polski numer. Jeśli turyści są już w Egipcie i nie rozmawiali z pracownikami biura w Polsce, wówczas mogą się z nim kontaktować również pod polskim numerem, nie narażając się na wysokie koszty połączenia.

Kolejne biuro - Esti Tours - organizuje wycieczki fakultatywne w bardzo dobrej cenie. Oferuje szeroki zakres wycieczek oraz daje możliwość korzystania z gotowych pakietów. Dla większej liczby osób (więcej niż sześciu) biuro ma bogatą ofertę i duże zniżki. Jeżeli klienci kupują dwie wycieczki, przysługuje im rabat 5\% od całkowitego 
kosztu. Jeśli są to trzy wycieczki, rabat wynosi 10\%. Jest też specjalny rabat dla osób, które wykupiły więcej niż trzy wycieczki - ponad 15\%.

Wszystkie polsko-egipskie biura podroży w Szarm el-Szejk mają podobną ofertę wycieczek fakultatywnych. Ze względu na sytuację polityczną w sezonie 2015 polskie Ministerstwo Zagraniczne skierowało ostrzeżenie do turystów przebywających na wakacjach w Egipcie, aby nie korzystali z dalekich wycieczek ani nie podróżowali do sąsiednich państw, takich jak Izrael czy Jordania. Niepokoje w Kairze i innych miastach wykluczyły z mapy turystycznej większość najciekawszych miejsc, istotnych dla turystyki kulturowej i krajoznawczej, najbardziej dla Egiptu dochodowej. W sezonie 2015 nie odbywały się wycieczki do Wielkich Piramid, Luksoru, Asuanu, Abu Simbel czy Aleksandrii. Do dyspozycji turystów pozostały jedynie krótkie, jednodniowe wycieczki w pobliżu nadmorskich kurortów.

Polsko-egipskie biura podróży nie organizowały w 2015 roku wycieczek w dalekie regiony, a swoją ofertę przekształciły i wzbogaciły o lokalne atrakcje. Po przeprowadzeniu wywiadów z właścicielami i pracownikami wymienionych wyżej biur można stwierdzić, że uważają sezon 2015 za udany, mimo niestabilności politycznej i uboższej oferty turystycznej. Choć oferta była mniej interesująca w porównaniu do lat ubiegłych, nie odbiło się to znacząco na ich zarobkach i dochodach. Dzięki temu, że do wyboru było mniej miejsc do odwiedzenia, biura mogły organizować wybrane wycieczki nawet codziennie, co okazało się dużym udogodnieniem dla turystów, którzy nie musieli planować swoich wypraw z wyprzedzeniem.

Do najpopularniejszych wycieczek fakultatywnych w roku 2015, organizowanych codziennie przez biuro E-Sharm.Pl, należały: safari na wielbłądach, kolacja beduińska, aqupark, delfinarium, aquascope, łódź ze szklanym dnem, Quad Safari, pokaz Alf Laila wa Laila, City Tour - Szarm el-Szejk, wycieczka do Parku Narodowego Ras Mohamed, rejs na wyspę Tiran oraz nurkowanie. Biuro PolSharm, poza wymienionymi wyżej, organizowało w poniedziałki, środy, piątki i soboty wycieczki do klasztoru św. Katarzyny i na górę Synaj, a w pozostałe dni do Kolorowego Kanionu na Synaju. Było to jedyne biuro, które w 2015 roku organizowało wycieczki w te miejsca. Biuro Esti Tours, aby być bardziej atrakcyjne na rynku, oferowało wycieczki do Białego Kanionu i na Białą Wyspę.

Oferty wszystkich fakultatywnych wycieczek w polsko-egipskich biurach podróży w Szarm el-Szejk są w bardzo podobnej cenie. Pomimo polityczno-ekonomicznych zawirowań, które od czterech lat mają miejsce w Egipcie, turystyka wciąż jest opłacalna, jednak w znacznie mniejszym stopniu niż przed rokiem 2011. Pracownicy biur podróży, z którymi rozmawiała autorka, niemal zgodnie stwierdzili, że w ponownym rozkwicie tego sektora gospodarki może pomóc ustabilizowanie się sytuacji w kraju, walka z terroryzmem - który od czasu rewolucji daje o sobie znać coraz częściej - i przede wszystkim zwiększenie ochrony i bezpieczeństwa w Egipcie. Wszelkiego rodzaju zamieszki bądź akty terroru powodują załamanie na runku turystycznym, generując ogromne straty dla całego kraju. Pracownicy twierdzą, że bez zapewnienia odpowiedniego bezpieczeństwa na nic zdadzą się choćby najlepsze plany i strategie Ministerstwa Turystyki. 


\section{OCENA ATRAKCYJNOŚCI POLSKO-EGIPSKICH BIUR PODRÓŻY W SZARM EL-SZEJK PRZEZ POLSKICH TURYSTÓW}

Głównym celem niniejszego artykułu jest przedstawienie zachowań konsumenckich Polaków korzystających z polsko-egipskich biur podróży na rynku turystycznym w Szarm el-Szejk. Zaprezentowane dane mówią o tym, jaką formę turystyki i wypoczynku preferują ankietowani w Egipcie, co skłoniło ich do skorzystania z usług danego biura podróży, jak dowiedzieli się o jego istnieniu, w ilu fakultatywnych wycieczkach uczestniczyli, czym kierowali się przy wyborze lokalnego biura oraz ile pieniędzy wydali. Dokonano również analizy najczęściej wybieranych przez polskich turystów wycieczek fakultatywnych oraz oceniono ich organizację.

Respondentom zadano pytanie o to, jakie najczęściej wybierają polsko-egipskie biuro podróży w Szarm el-Szejk (ryc. 1).

Ryc. 1. Najczęściej wybierane przez Polaków polsko-egipskie biuro podróży w Szarm el-Szejk

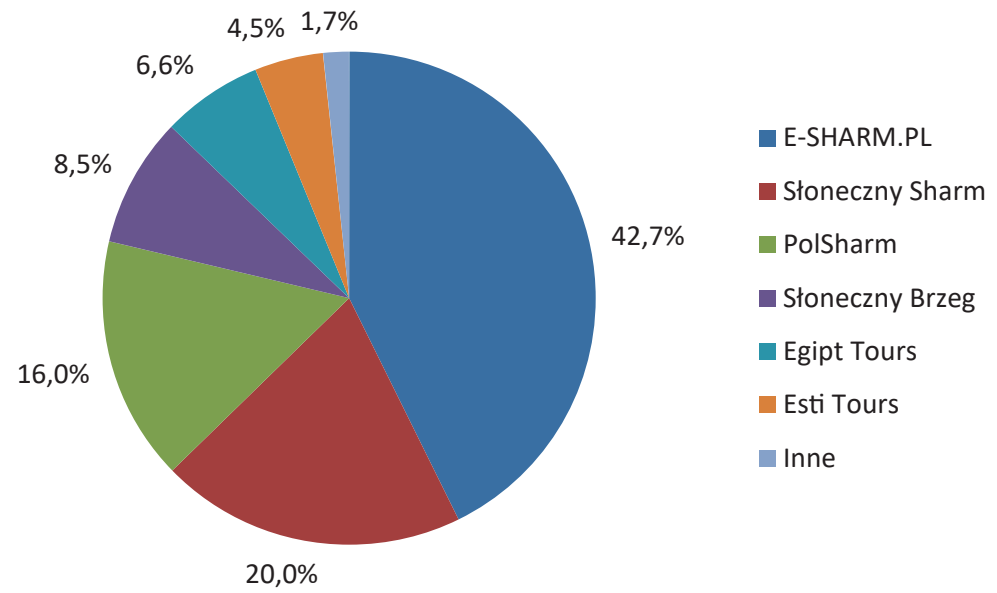

Źródło: opracowanie własne na podstawie przeprowadzonych badań

Polacy najczęściej wybierają biuro E-Sharm.Pl. Tak odpowiedziała prawie połowa z nich $(42,7 \%)$. Popularność tego biura podyktowana jest przede wszystkim bardzo dużą ofertą wycieczek oraz relatywnie niższymi w stosunku do innych biur cenami. Dość popularne są też biura Słoneczny Sharm (20\%) i PolSharm (16\%). Ankietowani korzystali również z usług biur podroży: Słoneczny Brzeg (8,5\%), Egipt Tours $(6,6 \%)$, Esti Tours $(4,5 \%)$ i innych $(1,7 \%)$.

Ankietowani poproszeni zostali również o zaznaczenie odpowiedzi, co według nich wpłynęło na to, że skorzystali z usług danego biura podróży jako organizatora wycieczki fakultatywnej (ryc. 2).

Niewątpliwie przystępna cena usługi $(37,8 \%$ ankietowanych) oraz reklama internetowa $(20,6 \%)$ są czynnikami, które przyciągają i powodują zainteresowanie polskich turystów ofertą danego biura. Rekomendacja biura podróży przez rodzinę $(16,5 \%)$ oraz 
Ryc. 2. Przyczyny korzystania Polaków z usług biura podróży jako organizatora wycieczki fakultatywnej

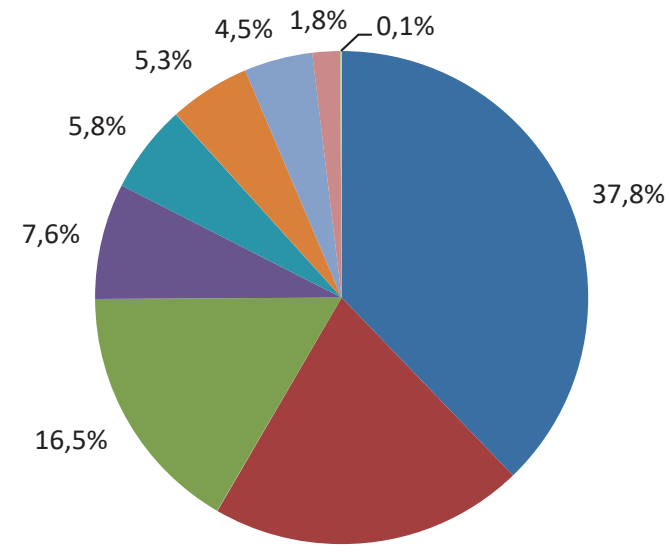

Przystępna cena

Reklama internetowa

Rekomendacja biura podróży przez rodzinę

Bogata oferta wycieczek

Możliwość elastycznego ustalenia terminu

Reklama w postaci ulotek

$20,6 \%$

Źródło: opracowanie własne na podstawie przeprowadzonych badań

Ryc. 3. Ocena polsko-egipskiego biura podróży przez badanych Polaków

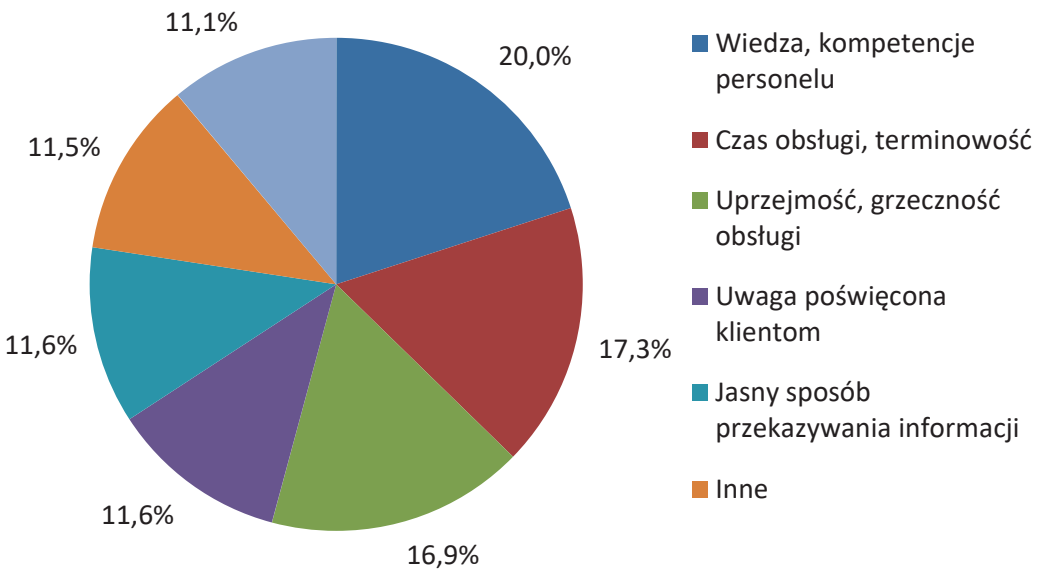

Źródło: opracowanie własne na podstawie przeprowadzonych badań

bogata oferta wycieczek $(7,6 \%)$ znalazły się na dalszym miejscu. Niektórzy ankietowani sugerowali, że praca Polaków jeszcze przed wylotem do Egiptu, w postaci rozdawanych ulotek, jest dla nich opłacalna (5,3\%). Choć w pytaniu tym zestawiono odpowiedzi dla wszystkich badanych biur, to po analizie kwestionariuszy należy stwierdzić, że najistotniejszymi przyczynami, dla których ankietowani wybrali biuro podróży E-Sharm.Pl, są przystępna cena i bogata oferta wycieczek. Dobra reklama internetowa i rekomendacja znajomych to cechy, które były najczęściej wymieniane wśród klientów biura Słoneczny Sharm, natomiast reklama w postaci ulotek oraz możliwość ustalenia elastycznego terminu wycieczki to cechy, które najczęściej wymieniali klienci biura PolSharm. 
Polscy turyści wypoczywający w Szarm el-Szejk, którzy skorzystali z oferty lokalnych biur podróży, bardzo wysoko ocenili ich działalność. Odpowiedzi na to pytanie obrazuje ryc. 3.

Najwyżej ocenione zostały wiedza i kompetencje personelu obsługującego polskich turystów (20\%). Terminowość, czas obsługi (17,3\%) oraz uprzejmość i grzeczność obsługi $(16,9 \%)$ znalazły się na kolejnych miejscach. Uwaga poświęcona klientom $(11,6 \%)$ oraz jasny sposób przekazywania informacji $(11,6 \%)$ przez polskojęzycznych Egipcjan pełniących funkcje pilotów i przewodników zostały bardzo dobrze ocenione. Dla 11,1\% ankietowanych najważniejsza była rzetelność biura oraz dotrzymywanie obietnic.

Polscy turyści o istnieniu polsko-egipskich biur podróży działających w Sharm el-Sheikh dowiedzieli się przede wszystkim z internetu (42,7\%) - por. ryc. 4. Ulotki i foldery znalazły się na drugim miejscu $(23,1 \%)$. Okazuje się, że dzięki istnieniu portali społecznościowych, takich jak Facebook, aż 21,8\% ankietowanych dowiedziało się o istnieniu lokalnego biura podróży. Reklama w hotelu $(3,1 \%)$ oraz informacja od rodziny i znajomych $(6,7 \%)$ nie były często wybieranymi odpowiedziami.

Ryc. 4. Źródło pochodzenia informacji o istnieniu lokalnego polsko-egipskiego biura podróży w Szarm el-Szejk

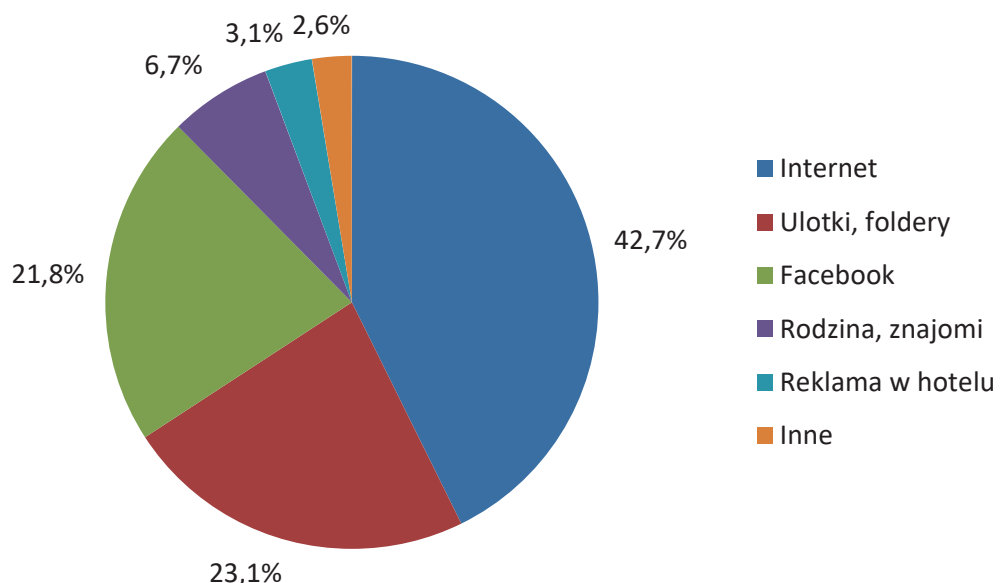

Źródło: opracowanie własne na podstawie przeprowadzonych badań

Autorka zapytała również o formę turystyki, jaką ankietowani preferują (ryc. 5). Polacy zdecydowanie najchętniej wybierali turystykę o charakterze poznawczym $(36,9 \%)$ i wypoczynkowym $(34,2 \%)$.

Egipt jest ciekawym miejscem zarówno dla profesjonalistów, jak i dla amatorów nurkowania, którzy nie posiadają uprawnień. Bardzo popularną rozrywką wśród turystów jest tzw. intro - można zejść na niewielką głębokość z profesjonalnym instruktorem i obejrzeć bogactwo raf koralowych Morza Czerwonego. Turystyka kwalifikowana (nurkowanie) znalazła się na trzecim miejscu wśród preferowanych przez Polaków form wypoczynku w Egipcie (18,2\%). 
Ryc. 5. Formy turystyki preferowane przez badanych Polaków w Egipcie

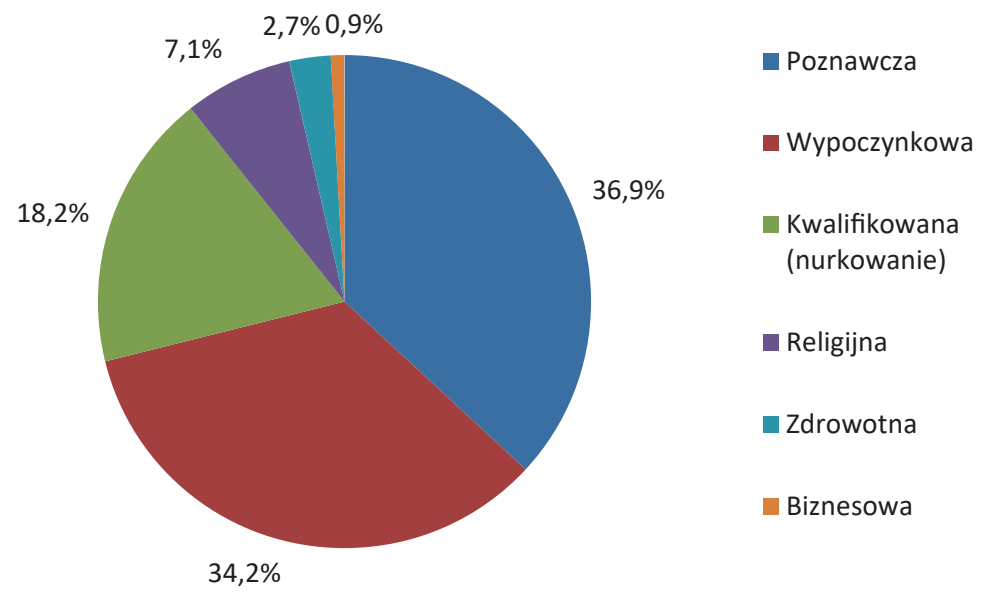

Źródło: opracowanie własne na podstawie przeprowadzonych badań

Ryc. 6. Liczba wycieczek, w których badani Polacy wzięli udział

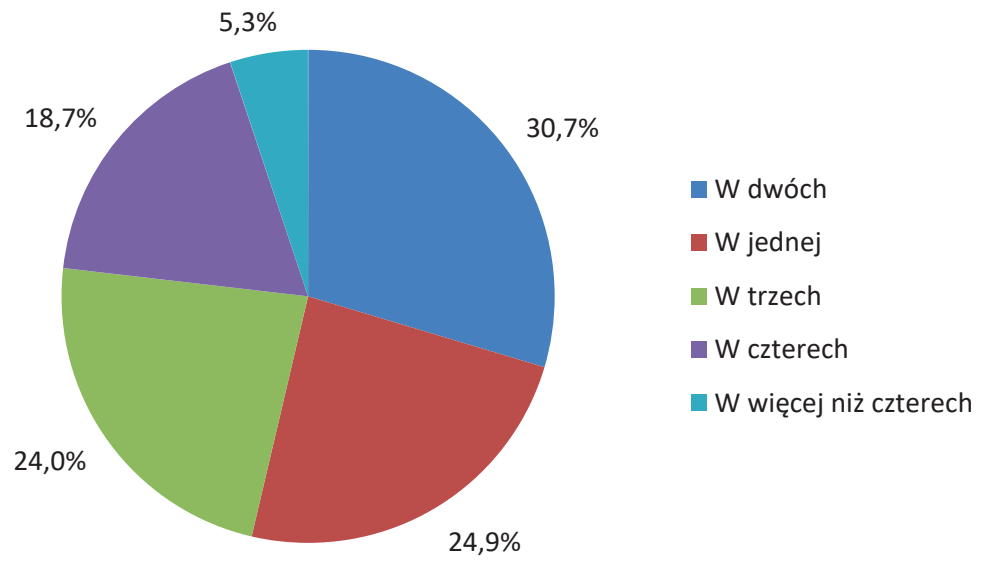

Źródło: opracowanie własne na podstawie przeprowadzonych badań

Możliwość odwiedzenia Góry Mojżesza i klasztoru św. Katarzyny na Synaju oraz przejazdu z Szarm el-Szejk do Izraela powoduje, że co roku część turystów wybiera turystykę religijną. W roku 2015 ze względów bezpieczeństwa obowiązywał zakaz podróżowania z Egiptu do Ziemi Świętej. Tylko biuro podróży Esti Travels zdecydowało się na organizację fakultatywnej wycieczki do klasztoru św. Katarzyny i nocnych wejść na Górę Mojżesza. Niewątpliwie przyczyniło się to do tego, że tylko 7,1\% ankietowanych w 2015 roku przyjechało do Egiptu w celach religijnych. 
Respondenci najczęściej brali udział w dwóch wycieczkach fakultatywnych podczas swojego wakacyjnego pobytu (30,7\%) (por. ryc. 6). Pośród ankietowanych znalazły się również takie osoby, które uczestniczyły w trzech (24\%), czterech $(18,7 \%)$, a nawet więcej niż czterech $(5,3 \%)$ wycieczkach. Jedna piąta Polaków $(24,9 \%)$ pojechała na jedną wycieczkę.

Polacy wydają w Egipcie znaczne sumy pieniędzy na fakultatywne wycieczki (ryc. 7). Aż 38,2\% z nich wydało w czasie swojego pobytu 150-200 dol. na osobę na dodatkowe wyjazdy. Od 200 do 300 dol. wydało $16 \%$ ankietowanych, a powyżej 300 dol. - 8,5\%. Tylko 5,8\% respondentów przeznaczyło na dodatkowe przyjemności w postaci wycieczek do 50 dol., co oznacza, że uczestniczyli oni w jednej takiej wycieczce.

Ryc. 7. Pieniądze wydane na wycieczki fakultatywne organizowane przez polsko-egipskie biura podróży działające w Szarm el-Szejk na jedną osobę (dol.)

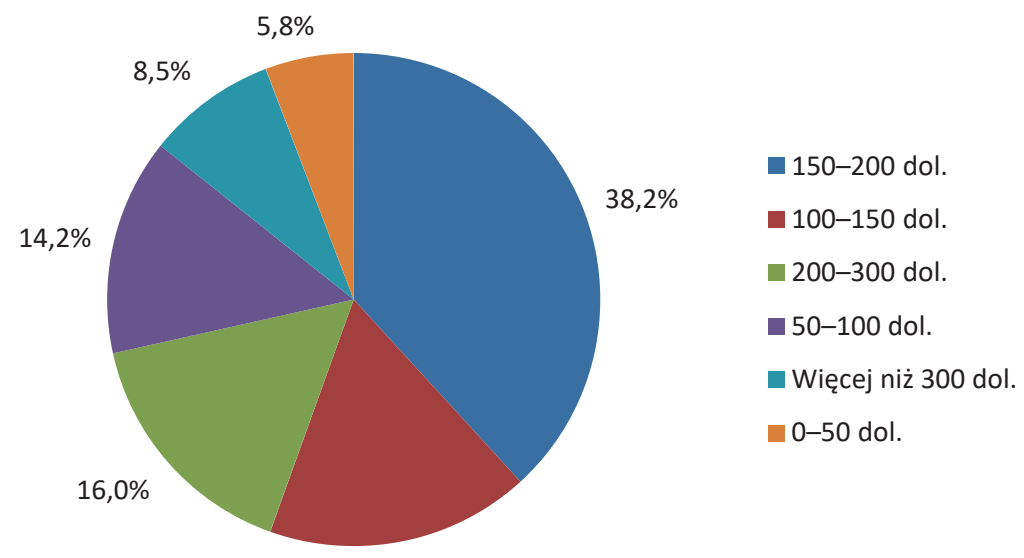

$17,3 \%$

Źródło: opracowanie własne na podstawie przeprowadzonych badań

Ważnym dla autorki pytaniem było to związane z wyborem konkretnej wycieczki oferowanej przez biuro podróży (ryc. 8). Ankietowani mogli w nim zaznaczyć więcej niż jedną odpowiedź.

Weźmy pod uwagę fakt, że turyści w 2015 roku nie mogli daleko podróżować i byli ograniczeni do lokalnych wycieczek. Po analizie odpowiedzi wyraźnie widać, że Polacy najchętniej i najczęściej płynęli w rejs na wyspę Tiran $(17,3 \%)$ i jeździli do Parku Narodowego Ras Mohamed (16\%). Na kolejnych miejscach znalazły się następujące wycieczki: delfinarium show $(10,2 \%)$, aquapark $(8 \%)$, nurkowanie $(7,1 \%)$, safari na quadach $(6,7 \%)$, supersafari (6,7\%), kolacja beduińska (5,3\%), klasztor św. Katarzyny (5,3\%), łódź ze szklanym dnem (4,9\%), pływanie z delfinami (4,1\%), safari Abu Galum $(4 \%)$ oraz aquascope $(1,3 \%)$.

Równie istotnym zagadnieniem było sprawdzenie, jakie destynacje i wycieczki fakultatywne wybraliby ankietowani, gdyby mieli możliwość swobodnego, bezpiecznego podróżowania po całym terytorium Egiptu. Odpowiedzi na to pytanie przedstawia ryc. 9. 
Ryc. 8. Najczęściej wybierane przez badanych Polaków wycieczki oferowane przez polsko-egipskie biura podróży w Szarm el-Szejk

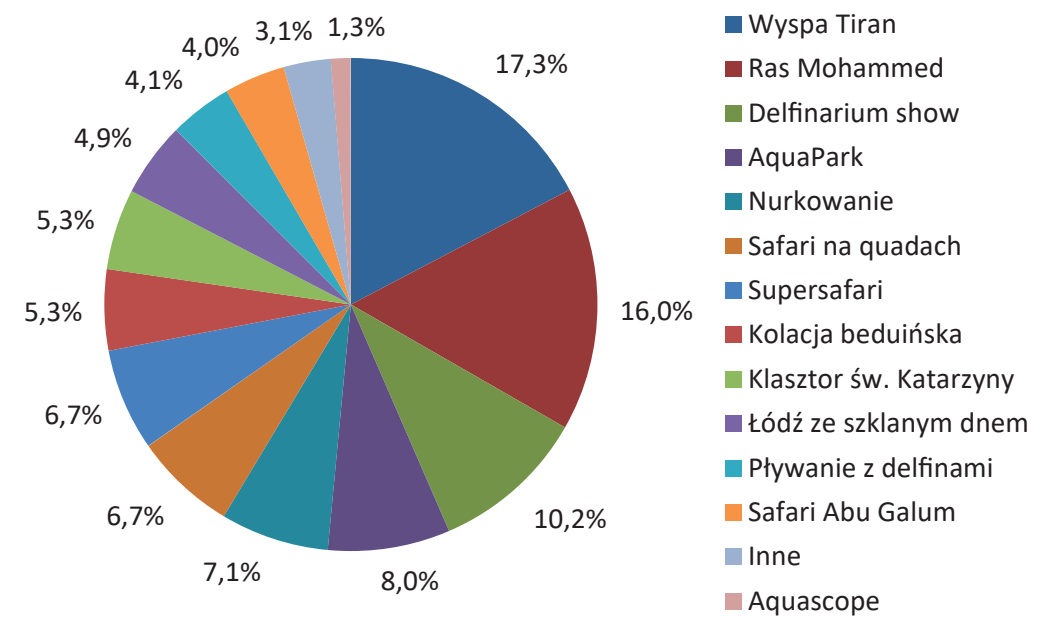

Źródło: opracowanie własne na podstawie przeprowadzonych badań

Ryc. 9. Chęć uczestnictwa ankietowanych w wycieczkach, gdyby nie była ograniczona ich dostępność
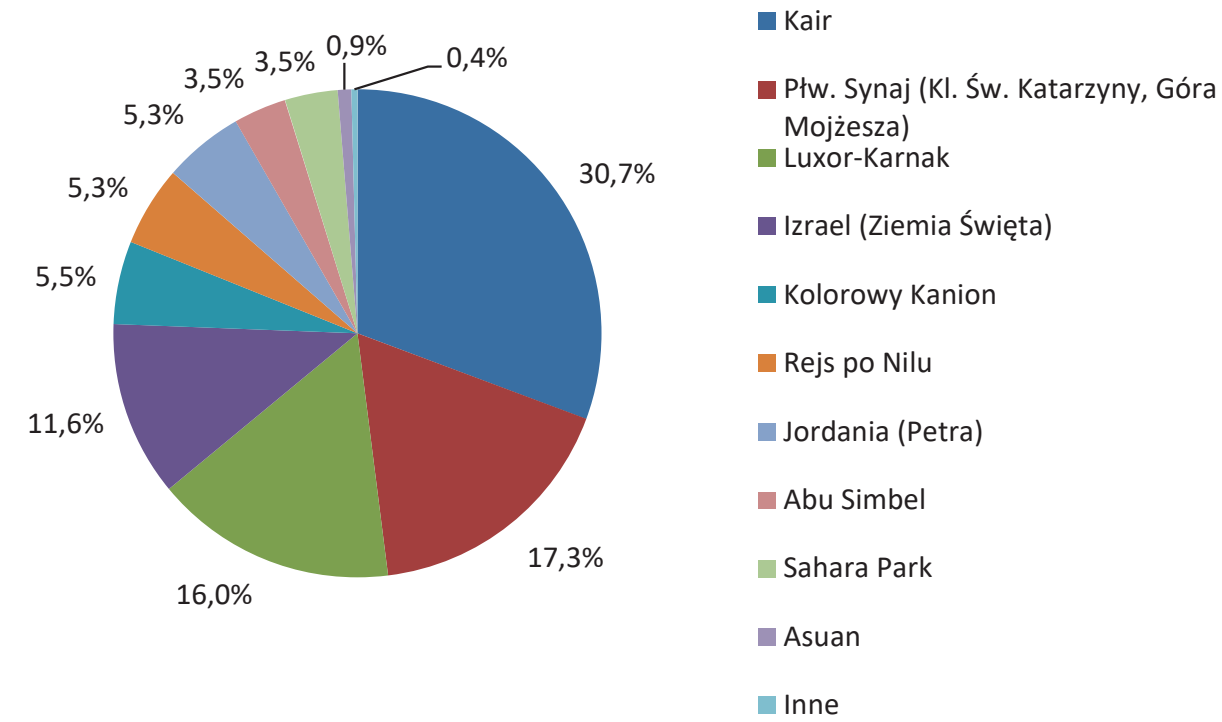

Źródło: opracowanie własne na podstawie przeprowadzonych badań

Okazuje się, że polscy turyści najchętniej pojechaliby do Kairu $(30,7 \%)$ oraz odwiedziliby klasztor św. Katarzyny (17,3\%). Pożądanym miejscem odwiedzin okazały się także starożytne zabytki Egiptu znajdujące się w Luksorze i Karnaku (16\%). Ankietowani wykazali również zainteresowanie wycieczkami do dwóch sąsiadujących krajów - Izraela (11,6\%) i Jordanii (5,3\%). Kolorowy Kanion (5,5\%), rejs po Nilu (5,3\%), Abu Simbel (3,5\%) oraz Sahara Park (3,5\%) znalazły się na kolejnych miejscach. 
Ostatnie pytanie, które znalazło się w kwestionariuszu, dotyczyło czynników, jakie miały wpływ na to, że ankietowani wybrali Egipt na miejsce swoich wakacji (ryc. 10). Najczęściej wskazywano na wypoczynek (26,2\%) oraz bogactwo fauny i flory $(21,3 \%)$, które Egipt ma do zaoferowania. Zabytki starożytnego Egiptu, pomimo tego, że były niedostępne dla zwiedzających, znalazły się na trzecim miejscu $(18,2 \%)$. Klimat, słońce i morze $(16 \%)$, rekomendacje znajomych $(8,5 \%)$ oraz poznanie odmiennej kultury $(8,5 \%)$ były rzadziej wybieranymi odpowiedziami.

Ryc. 10. Czynniki wpływające na wybór wakacji w Egipcie przez badanych Polaków

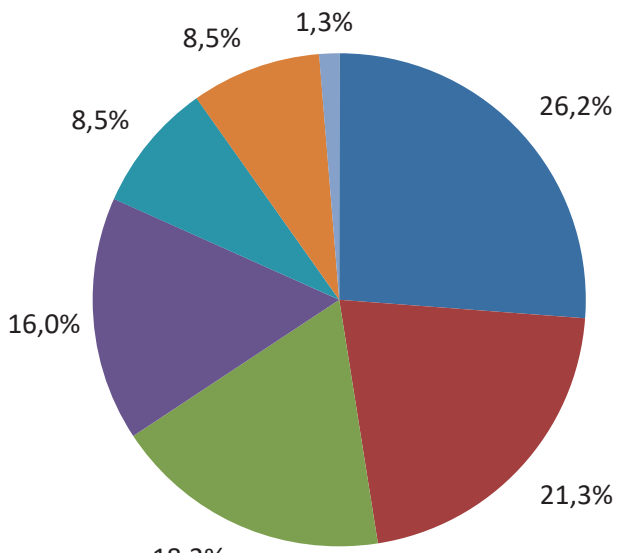

$18,2 \%$
- Wypoczynek

Bogactwo fauny i flory

Zabytki starożytnego Egiptu

Klimat, słońce, morze

Rekomendacje znajomych

Poznanie odmiennej

kultury

Inne

Źródło: opracowanie własne na podstawie przeprowadzonych badań

\section{ZAKOŃCZENIE}

Egipt od dawna zaliczany jest do najpopularniejszych celów wizyt polskich turystów. Jest to bowiem kraj o niezwykle bogatej kulturze i wyjątkowej historii; w dodatku znajduje się w relatywnie niedużej odległości od Polski, przez co wycieczki są stosunkowo tanie. Wiele jednak zmieniło się po roku 2011, kiedy to na fali arabskiej wiosny państwo to zaczęło być dość niespokojne. Sytuacja w Egipcie budzi wiele obaw u osób, które planują spędzić tam wakacje. Teoretycznie, po początkowych niepokojach związanych ze zmianą władzy, sytuacja powoli się stabilizuje. Jednak w rzeczywistości kraj ten jest nadal politycznie niespokojny, coraz większe poparcie i siłę zdobywają ugrupowania tworzone przez islamskich ekstremistów - np. słynne Bractwo Muzułmańskie. $\mathrm{Z}$ drugiej strony, turystyczne regiony są względnie bezpieczne i cały czas odwiedzane przez polskich turystów.

Działalność polsko-egipskich biur podróży w największych kurortach, takich jak Szarm el-Szejk czy Hurghada, pokazuje, że wśród polskich turystów jest duże zainteresowanie i zapotrzebowanie na usługi tych firm. Jak pokazały przeprowadzone badania, właściciele i pracownicy biur podróży, pomimo polityczno-gospodarczych trudności, z jakimi od kilku lat muszą się mierzyć, nie narzekają na brak klientów. Przykład 
polsko-egipskiego biura Esti Travel, które na rynku w Szarm el-Szejk działa od dwóch lat, udowadnia, że jest to dziedzina gospodarki przynosząca stałe dochody. Właściciele biur mieli nadzieję, że konferencja ekonomiczna, która odbyła się w Szarm el-Szejk w marcu 2015 roku na zlecenie prezydenta Abd al-Fattaha as-Sisiego, poprawi ich sytuację. Prezydent podkreślał, że Egipt jest bezpiecznym i wartym odwiedzenia krajem.

Przeprowadzone badania ankietowe pokazały, że:

- najpopularniejszymi wśród Polaków polsko-egipskimi biurami działającymi w Szarm el-Szejk są E-Sharm.Pl i Słoneczny Brzeg - ze względu na bardzo bogatą ofertę wycieczek i relatywnie niższe w stosunku do innych biur ceny,

- przystępna cena wycieczki oraz reklama internetowa były głównymi czynnikami, z powodu których turyści wybierali dane biuro,

- głównym źródłem wiedzy na temat biura podróży były: internet, ulotki oraz Facebook,

- ankietowani najczęściej brali udział w dwóch fakultatywnych wycieczkach oraz średnio wydawali 150-200 dol. na osobę,

- w 2015 roku Polacy w Szarm el-Szejk za pośrednictwem polsko-egipskich biur podróży najczęściej uczestniczyli w wycieczce na wyspę Tiran oraz do Parku Narodowego Ras Mohamed,

- natomiast najchętniej pojechaliby do Kairu i Luksoru.

M.S. Hanna w swoim artykule (2013) skupiła się na wpływie polityki rządu na sektor turystyczny w latach 2011-2013. Podkreśla ona ogromny wpływ turystyki na rozwój gospodarczy kraju oraz na tworzenie nowych miejsc pracy. Sektor turystyczny wraz ze spadkiem liczby turystów odnotował straty przychodów. Zaistniała sytuacja zmusiła właścicieli biznesów turystycznych - m.in. właścicieli lokalnych biur turystycznych, do obniżenia cen świadczonych usług. Niższe ceny wycieczek w lokalnych biurach podróży w porównaniu do bardzo podobnej, ale dużo droższej, oferty kupionej bezpośrednio u rezydenta opiekującego się turystami podczas wakacji w hotelu powoduje, że polsko-egipskie biura podróży działające w Szarm el-Szejk miały i będą mieć swoich klientów.

\section{Literatura}

\section{References}

Abdou, D.S., Zaazou, Z. (2013). The Egyptian Revolution and post Socio-economic impact. Topics in Middle Eastern and African Economies, 15, 92-115.

$\mathrm{Al}$ Hamarneh, A. (2006). Economic growth, social development and international tourism - cases from the Arab World. Imagine there is no countries - Inequality and Growth in Age of Tourism, 5th Interanational Symposium on Tourism and Sustainability, conference handbook.

Campas (2015, 12 grudnia). Pozyskano z www.capmas.gov.eg

Cook, S., Perry, T., Ward, G. (2008). USA część zachodnia, praktyczny przewodnik. Bielsko-Biała: Wydawnictwo Pascal.

Dziedzic, T., Łopaciński, K., Saja, A., Szegidewicz, J. (2009). Wpływ światowego kryzysu gospodarczego na stan i perspektywy rozwoju sektora turystyki w Polsce. Warszawa: Departament Turystyki Ministerstwa Sportu i Turystyki.

Fiedler, R. (2014). Arabska Wiosna - szanse i wyzwania dla polityki USA wobec Bliskiego Wschodu. Przegląd Politologiczny, 1, 33-49. 
Flick, U. (2012). Projektowanie badania jakościowego. Warszawa: PWN.

Gotowt-Jeziorska, A., Łopaciński, K. (red.) (2011). Turystyka w Polsce w okresie kryzysu. Warszawa: Polskie Stowarzyszenie Turystyki.

Gray, M. (1998). Economic reform, privatization and tourism in Egypt. Middle Eastern Studies, 34(2), 91-112.

Hanna, M.S. (2013). The Tourism Crisis in post January 25th Egypt. Kair: The American University in Cairo.

Jemielniak, D. (2012). Czym są badania jakościowe? W: D. Jemielniak (red.). Badania jakościowe: Podejścia i teorie. Warszawa: PWN.

Kurek, S., Wacławik, P. (2013). Zróżnicowanie zagranicznej turystyki przyjazdowej w Unii Europejskiej w czasie kryzysu gospodarczego. Prace Komisji Geografii Przemysłu Polskiego Towarzystwa Geograficznego, 24, 9-24.

Marciniak, M., Dłużewska, A. (2015). Wpływ Wiosny Arabskiej na turystykę w Egipcie. Turystyka Kulturowa, 9.

Mazurek-Łopacińska, K. (2005). Badania marketingowe. Warszawa: PWN.

Mika, M., Faracik, R. (2008). Międzynarodowy ruch turystyczny. W: W. Kurek (red.). Turystyka. Warszawa: PWN, 66-120.

Sattin, A., Franquet, S. (2003). Przewodnik po Egipcie. Bielsko-Biała: Wydawnictwo Pascal.

Silverman, D. (2008). Prowadzenie badań jakościowych. Warszawa: PWN.

Tohamy, S., Swinscoe, A. (2000). The economic impact of tourism in Egypt. The Egyptian Center for Economic Studies, 40.

UNWTO (2013). Tourism Highlights.

Zdanowski, J. (2013). Znaczenie Arabskiej Wiosny. Krakowskie Studia Bliskowschodnie, 3, 13-32.

Zdon-Korzeniowska, M., Rachwał, T. (2011). Turystyka w warunkach światowego kryzysu. Prace Komisji Geografii Przemysłu Polskiego Towarzystwa Geograficznego, 18, 116-128.

Kamila Ziółkowska-Weiss, dr, absolwentka kulturoznawstwa z historią sztuki na Uniwersytecie Jagiellońskim oraz geografii na Uniwersytecie Pedagogicznym w Krakowie. Ukończyła podyplomowe studia na Uniwersytecie Ekonomicznym w Krakowie na kierunku zarządzanie turystyką międzynarodową. Od 2012 roku pracownik naukowy na stanowisku asystent w Zakładzie Turystyki i Badań Regionalnych Uniwersytetu Pedagogicznego w Krakowie. Czynny pilot wycieczek. Autorka kilkunastu publikacji naukowych. Główne zainteresowania naukowe to turystyka kulturowa, mniejszości narodowe i grupy etniczne w Małopolsce oraz Polonia w USA.

Kamila Ziółkowska-Weiss, Ph.D. Graduate studies at the Jagiellonian University and of Geography on the Pedagogical University in Krakow. She has graduated from postgraduate studies in international tourism management at the Cracow University of Economics. Since 2012 she has been a research worker, acting as a teaching assistant in the department of Tourism and Regional Studies at the Pedagogical University in Krakow. She is an active tourist guide and the author of several academic publications. Her main academic interests include cultural tourism, ethnic groups in Małopolska, and the Polish minority in the USA.

\section{Adres/address:}

Uniwersytet Pedagogiczny w Krakowie Instytut Geografii

Zakład Turystyki i Badań Regionalnych

ul. Podchorążych 2, 30-084 Kraków, Polska

e-mail: kamilacamela@wp.pl 